ISSN 1392-3196 / e-ISSN 2335-8947

Zemdirbyste-Agriculture, vol. 106, No. 2 (2019), p. 129-134

DOI 10.13080/z-a.2019.106.017

\title{
Improving potato microclone productivity by exogenous application of proline, glutamic acid and stem decapitation
}

\author{
Liudmila TRIPOLSKAJA, Almantas RAZUKAS \\ Lithuanian Research Centre for Agriculture and Forestry, Voke Branch \\ Žalioji 2, Vilnius, Lithuania \\ E-mail: liudmila.tripolskaja@lammc.lt
}

\begin{abstract}
Various growth regulators are used for plant stress reduction. They help to maintain the osmotic pressure required in cells and protect against increased saline concentration in the nutrition medium. The purpose of the experiment was to determine the influence of bioactive products produced from amino acids: proline amino acid (PAA) Prolis, and glutamic amino acid and potassium sulphate $\left(\mathrm{GAA}-\mathrm{K}_{2} \mathrm{SO}_{4}\right)$ Pompa, and stem decapitation on the formation of potato (Solanum tuberosum L.) minitubers of early cultivar 'Goda' and very late cultivar 'VB Aista' with different durat ion of plant ontogenesis. Amino acid products were used once (after potato microclone transplanting to the substrate) or twice (after microclone transplanting to the substrate and after 30 days) during the growing season. Stem decapitation was performed at growth stages BBCH 51 and 57. The influence of PAA and GAA-K $\mathrm{SO}_{4}$ on the productivity of microclones was found to depend on the potato genotype. The minituber weight of potato late cultivar 'VB Aista' increased significantly $(P<0.05)$ after treating plants with GAA-K $\mathrm{SO}_{4}$ once or twice during the growing season. Stem decapitation at stage BBCH 57 significantly increased the minituber weight of both cultivars and the number of minitubers of 'VB Aista'. A strong positive correlation was established between the minituber weight and nitrogen concentration in the potato leaves at the flowering stage.
\end{abstract}

Key words: bioactive product, glutamine, minituber, osmoprotectant, proline.

\section{Introduction}

A widely used method in the modern potato seed production is meristem tissue multiplication, when free from viruses, bacterial and fungal infection potato sprout meristem cells are separated and microclone plants in vitro are grown. In this way, both healthy virus free potato plants and rapidly multiplied potato seed are obtained (Dimante, Gaile, 2014). The microclone plants grown in vitro are transferred to greenhouses for further cultivation. During transplanting the microclone root system is partially damaged, therefore, it is extremely difficult for them to adjust to the water balance in the early days. In addition, the plants enter a different nutrient medium with higher salt concentrations which can lead to stress. In order to restore damaged water balance, plants begin to accumulate more specific metabolites in cells such as mannitol, proline, glycine betaine and various sugars (Valentovič et al., 2006; Chen et al., 2007). Increased proline concentration ensures the stability of cell osmotic potential and protects the structure of macromolecules and organelles (Haghighi et al., 2012). To increase plant resistance to stress, different measures such as poly $\gamma$-glutamic acid (Lei et al., 2016), proline, $\gamma$-aminobutyric acid (Ali et al., 2008; Farooq et al., 2017), macronutrient potassium $(\mathrm{K})$, which play an important role in osmotic adjustment (Ahmad et al., 2018), and bacterium Azospirillum brasilence (Tkachenko et al., 2015) are also used.

Foliar application of proline increases plant yield, plant height, leaf number and stimulates the growth of root system (El-Sherbeny, Teixeira da Silva, 2013), as well as activates nitrogen uptake and the synthesis of amino acids and chlorophyll (Takeuchi et al., 2008). Farzana (2014) found that foliar application of proline increased wheat drought tolerance, which increased grain yield. The optimal proline concentration was $50 \mathrm{mM}$. Exogenous proline significantly increased plant growth and nitrogen assimilation; however, the effect depends both on the plant species and the cultivar. In the review on exogenous proline application for plants Hayat et al. (2012) suggest that proline increases plants stress tolerance when low concentrations are used.

The multiplication rate of potato minitubers depends on the root system and the number of stolons on which the minitubers form. Bioactive substances and other means can stimulate the development of these plant organs. One of these ways is the removal of

Please use the following format when citing the article:

Tripolskaja L., Ražukas A. 2019. Improving potato microclone productivity by exogenous application of proline, glutamic acid and stem decapitation. Zemdirbyste-Agriculture, 106 (2): 129-134. DOI 10.13080/z-a.2019.106.017 
plant stem tops - stem decapitation. After decapitation, axillary buds start to grow, growth energy increases and larger foliage forms. It has been established that such a measure increases the formation of minitubers and, accordingly, the overall productivity of plants; however, the effectiveness depends on the development stage of plants and the potato genotype (Desta, Tsegaw, 2008). Evstratova and Nikolaeva (2016) published the opposite data. They established that the stem decapitation increased the area of an assimilation surface of plants, but the yield of potato tubers decreased. According to Bautista Condori et al. (2018), stem decapitation had no effect on the tuber yield in the three native potato varieties evaluated in Bolivia. Stem decapitation is applied in the organic potato seed production technology in the Netherlands (Struik, Wiersema, 2012).

The purpose of this study was to determine the effect of biologically active products based on amino acids (PAA and GAA- $\mathrm{K}_{2} \mathrm{SO}_{4}$ ) and stem decapitation on the productivity of potato meristem microclones of early cultivar 'Goda' and very late cultivar 'VB Aista' with different duration of plant ontogenesis.

\section{Materials and methods}

The experiment was conducted at Vokè Branch of the Lithuanian Research Centre for Agriculture and Forestry in 2015-2017. Meristem microclone plants of potato (Solanum tuberosum L.) early cultivar 'Goda' and very late cultivar 'VB Aista' were tested. Each experiment consisted of 560 microclone plants. The plants were grown in vitro up to two-leaf stage $(2-3 \mathrm{~cm}$ long). At the beginning of April, microclones were planted in greenhouses with controlled air temperature, 1 plant per polyethylene cylindrical pot. The pot diameter was $20 \mathrm{~cm}$, height $-20 \mathrm{~cm}$, pot volume $-6280 \mathrm{~cm}^{3}$. Microclone plants from plantlets were grown in a peatbased growing medium; substrate $\mathrm{pH}_{\mathrm{H} 2 \mathrm{O}} 6.0$, plant available $\mathrm{P}_{2} \mathrm{O}_{5} 300-350 \mathrm{mg} \mathrm{kg}^{-1}$, plant available $\mathrm{K}_{2} \mathrm{O}$ $350-400 \mathrm{mg} \mathrm{kg}^{-1}$.

The experimental design. Factor A - potatoes of different ontogeny duration (meristem microclone plants): 1) 'Goda' (early, growing period 90-100 days) and 2) 'VB Aista' (very late, growing period 120 d.+). Factor B - measures to stimulate potato rhizogenesis and minituber formation: 1) background (fertilization with NPK fertilizers), 2) stress reduction product proline amino acid (PAA) Prolis after transferring plants to substrate (PAA 1), 3) stress reduction products PAA and glutamic amino acid and potassium sulphate (GAA$\mathrm{K}_{2} \mathrm{SO}_{4}$ ) Pompa increasing cellular osmotic pressure (osmoprotectant) after transferring plants to substrate $\left(\mathrm{PAA}+\mathrm{GAA}_{2} \mathrm{SO}_{4}\right.$ 1), 4) stress reduction product PAA twice during the growing season (after planting to substrate and after 30 days via leaves) (PAA 2), 5) stress reduction products $\mathrm{PAA}$ and $\mathrm{GAA}-\mathrm{K}_{2} \mathrm{SO}_{4}$ twice during the growing season (after planting to substrate and after 30 days via leaves) (PAA $\left.+\mathrm{GAA}^{-} \mathrm{K}_{2} \mathrm{SO}_{4} 2\right), 6$ ) removal of potato stem tops at the inflorescence (cyme) emergence (stage BBCH 51), and 7) removal of potato stem tops at the inflorescence (cyme) emergence (stage BBCH 57).

The characteristic of the tested products. Proline amino acid (PAA) product Prolis, soluble crystalline substance, contains pure $99.5 \% \mathrm{~L}-\alpha$-proline. The product is intended to reduce biotic and abiotic stress; it regulates the absorption of macro- and microelements and stimulates the mechanisms of natural defence of plants. Glutamic amino acid (GAA- $\mathrm{K}_{2} \mathrm{SO}_{4}$ ) product Pompa, concentrated, soluble, easy to absorb fertiliser, contains L- $\alpha$-glutamic amino acid $196 \mathrm{~g} \mathrm{~kg}^{-1}$, potassium $344 \mathrm{~g} \mathrm{~kg}^{-1}$ and sulphur $144 \mathrm{~g} \mathrm{~kg}^{-1}$. It is used to increase the osmotic pressure of plant cells.

Plant fertilization. Before transferring the plants to the greenhouse, the substrate in all treatments was fertilized with a complex fertilizer with a nitrification inhibitor Novatec Classic 12-8-16 $\left(\mathrm{N}_{60}\right) 1.57 \mathrm{~g}$ per pot. The PAA was used as a solution of $0.005 \%$ concentration at $50 \mathrm{ml}$ per pot (treatments 2 and 4 ) or a mixture of PAA $(0.005 \%)$, and GAA-K $\mathrm{SO}_{4}(0.5 \%)$ - at $50 \mathrm{ml}$ per pot (treatments 3 and 5). Stem decapitation was performed at the inflorescence emergence stage $(\mathrm{BBCH} 51$, first 1-2 $\mathrm{mm}$ individual buds of first inflorescence visible of main stem) and at the stage BBCH 57 (buds of second inflorescence extended to $5 \mathrm{~mm}$ open of main stem). During decapitation, 6-8 cm of stem tops was removed.

Chemical analyses. Nitrogen (N) (by the Kjeldahl method) and carbohydrate (First Commission Directive 71/250/EEB) concentrations were determined in potato leaves during the flowering stage. The recording of minituber yields was carried out at the full maturity stage. A tuber weight (g) per plant and the amount of tubers were determined.

Statistical analysis. The data were evaluated by a two-factor analysis of variance (ANOVA) using the Fisher's test $(P<0.05)$. Duncan's post-hoc test $(P<0.05)$ was used to carry out multiple comparisons for potato cultivars. A correlation-regression analysis of data was performed to determine the strength and nature of the relationship between the variables. The relationship between individual indicators was estimated by using correlation coefficient $R$ and determination coefficient $R^{2}$ at a probability level of $95 \%$.

\section{Results and discussion}

The biochemical analysis of leaves conducted during the potato flowering stage showed that nitrogen concentration in them depended on the length of the growing period of the cultivar and the measures taken. A higher nitrogen concentration was observed in the leaves of potato cultivar 'VB Aista' which has a longer growing period compared to an early cultivar 'Goda' $(P<0.05)$ (Fig. 1). Plant treatment with amino acid products PAA or GAA- $\mathrm{K}_{2} \mathrm{SO}_{4}$ increased nitrogen uptake and nitrogen concentration in the leaves of 'Goda' increased by on average $32.7-72.5 \%$, and by $32.0-135.9 \%$ in the leaves of 'VB Aista' compared to the control treatment.

A higher nitrogen concentration in 'Goda' leaves was determined after using products PAA and GAA$\mathrm{K}_{2} \mathrm{SO}_{4}$ twice during the growing season, and the repeated treatment of 'VB Aista' plants with amino acid products after 30 days did not change nitrogen concentration significantly. A similar effect of L-proline on nitrogen uptake is described in the publication by Takeuchi et al. (2008) and Teh et al. (2016). Assimilation of nitrogen $(\mathrm{N})$ and other elements $(\mathrm{P}, \mathrm{K})$ is also enhanced by the combination of L-proline with potassium nitrate $\left(\mathrm{KNO}_{3}\right)$ (Kaya et al., 2006). Alwan and Fathi (2013) found that increasing potassium levels from 0.5 to $2.0 \mathrm{~g}$ per pot increased $\mathrm{N}, \mathrm{P}$ and $\mathrm{K}$ adsorption of roselle (Hibiscus 


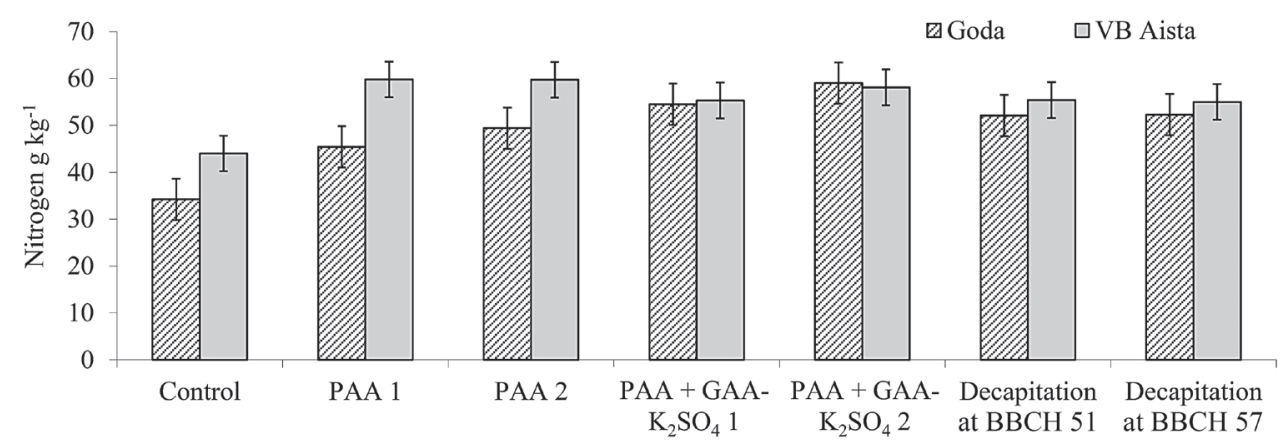

Note. Error bars indicate least significant difference at the $95 \%$ probability level $\left(\mathrm{LSD}_{05}\right)$

Figure 1. The influence of bioactive products and stem decapitation on nitrogen concentration in potato leaves at the flowering stage (BBCH 69)

sabdariffa L.) by $52.9,12.4$ and $25.0 \%$, respectively, and an increase in proline dosage from 0 to $150 \mathrm{mg} \mathrm{L}^{-1}$ induced higher assimilation of the above mentioned elements by $165.1,101.9$ and $162.6 \%$, respectively. Similar data of proline influence on photosynthetic activity were published by Zahoor et al. (2017).

Stem decapitation increased nitrogen assimilation in plants by promoting the growth of new organs, and its concentration in the leaves of 'Goda' increased by $52.3-52.9 \%$ and in the leaves of 'VB Aista' - by 25.9-25.0\% compared to the control treatment, and its effect was similar to that of PAA and GAA- $\mathrm{K}_{2} \mathrm{SO}_{4}$. Decapitation time (BBCH 51 or 57) as well as differences in ontogenesis duration of the cultivars, did not affect this indicator $(P>0.05)$.
During photosynthesis, the synthesis of organic compounds takes place in plant leaves. These compounds are further used for the formation of new tissues or, as a source of energy, participate in other biochemical processes. Analyses of carbohydrate concentrations in potato leaves during flowering showed that in the control treatment they ranged from 32.6 to $65 \mathrm{~g} \mathrm{~kg}^{-1}$ (Fig. 2). More carbohydrates were found in the plants of 'Goda' of a shorter growing period. Plant treatment with PAA or its mixture with GAA- $\mathrm{K}_{2} \mathrm{SO}_{4}$ decreased carbohydrate concentrations in the leaves by 62.391.1\%. Carbohydrate concentrations decreased more in the plants of 'Goda'. Ben Ahmed et al. (2010) found that proline supplement mitigated the reduction of plant growth and photosynthetic activity under salt stress and

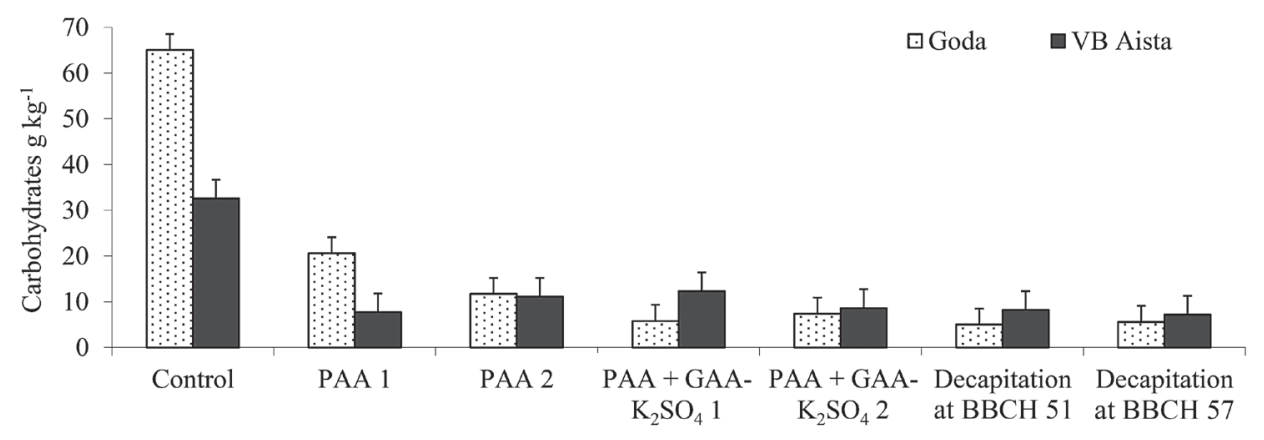

Note. Error bars indicate least significant difference at the $95 \%$ probability level $\left(\mathrm{LSD}_{05}\right)$

Figure 2. The influence of bioactive products and stem decapitation on carbohydrate concentration in potato leaves at the flowering stage (BBCH 69)

the decreased soluble sugars content in plants showed important osmoprotectant effect.

Of all the measures investigated, the highest reduction in carbohydrate concentrations resulted from stem decapitation. They decreased by $91.4-92.3 \%$ in the leaves of 'Goda' and by 74.8-77.9\% in 'VB Aista'. The decapitation time (BBCH 51 or 57) did not affect the changes in this indicator. The decrease in carbohydrate levels may be associated with the effect of amino acids activating plant nutrition, which increases the flow of assimilates from leaves to roots, as they are required as building material for the formation of new roots. The decrease in carbohydrate and starch concentrations with the increase in nitrogen concentration in plants was determined in the experiments with other plants as well (Nunes et al., 2014).
Weight of potato minitubers. After completing minituber weight recording at the full maturity stage, it was found that potatoes with different lengths of the growing season produced similar minituber yields. The minituber weight per plant of the early cultivar 'Goda' averaged $132.3 \mathrm{~g}$ and late cultivar 'VB Aista' - $125.5 \mathrm{~g}$ $(P>0.05)$ (Table). Microclone treatment with PAA and GAA-K $\mathrm{SO}_{4}$ products had a positive effect on minituber weight. The yield of minitubers increased more (31.3$46.8 \%$ ) after plant treatment with PAA once or twice during the growing season or having applied a mixture of PAA and GAA- $\mathrm{K}_{2} \mathrm{SO}_{4}$ twice during the growing season.

Stem top removal increased minituber weight as well, but a significant increase $(+31.2 \%, P<0.05)$ in yield was determined only after decapitation at the stage BBCH 57. Duncan's test assessed the effect of 
Table. The influence of bioactive products proline amino acid (PAA) Prolis and glutamic amino acid and potassium sulphate $\left(\mathrm{GAA}_{-} \mathrm{K}_{2} \mathrm{SO}_{4}\right)$ Pompa, and stem decapitation on potato microclone productivity

\begin{tabular}{|c|c|c|c|c|c|c|}
\hline \multirow{3}{*}{$\begin{array}{l}\text { Bioactive product } \\
\quad \text { (factor B) }\end{array}$} & \multicolumn{6}{|c|}{ Cultivar (factor A) } \\
\hline & \multicolumn{3}{|c|}{ Minituber weight g per plant } & \multicolumn{3}{|c|}{ Number of minitubers per plant } \\
\hline & Goda & VB Aista & Factor B average & Goda & VB Aista & Factor B average \\
\hline$\overline{\text { Background (NPK) }}$ & $124.2 \mathrm{ab}$ & $72.3 \mathrm{a}$ & 102.7 & $7.32 \mathrm{ab}$ & $7.15 \mathrm{a}$ & 7.81 \\
\hline PAA 1 & $128.7 \mathrm{ab}$ & $99.4 \mathrm{ab}$ & $150.8^{*}$ & $7.38 \mathrm{ab}$ & $7.44 \mathrm{a}$ & 8.31 \\
\hline $\mathrm{PAA}+\mathrm{GAA}-\mathrm{K}_{2} \mathrm{SO}_{4} 1$ & $130.4 \mathrm{ab}$ & $128.8 \mathrm{bc}$ & $134.8^{*}$ & $8.18 \mathrm{ab}$ & $7.71 \mathrm{abc}$ & 9.15 \\
\hline $\mathrm{PAA}+\mathrm{GAA}-\mathrm{K}_{2} \mathrm{SO}_{4} 1$ & $133.2 \mathrm{ab}$ & $129.8 \mathrm{bc}$ & 111.6 & $8.46 \mathrm{ab}$ & $8.08 \mathrm{abc}$ & 8.06 \\
\hline $\mathrm{PAA}+\mathrm{GAA}-\mathrm{K}_{2} \mathrm{SO}_{4} 2$ & $139.9 \mathrm{ab}$ & $136.4 \mathrm{c}$ & $141.2 *$ & $8.64 \mathrm{ab}$ & $8.76 \mathrm{abc}$ & 8.14 \\
\hline Decapitation at $\mathrm{BBCH} 51$ & $146.0 \mathrm{ab}$ & 139.0 cde & 126.5 & $8.68 \mathrm{ab}$ & $8.89 \mathrm{abc}$ & 8.13 \\
\hline Decapitation at BBCH 57 & $146.0 \mathrm{~b}$ & $172.8 \mathrm{e}$ & $134.7 *$ & $8.92 \mathrm{~b}$ & $9.66 \mathrm{c}$ & 8.04 \\
\hline Factor A average & 132.3 & 125.5 & & 8.22 & 8.24 & \\
\hline $\mathrm{LSD}_{05}$ factor $\mathrm{A}$ & \multicolumn{2}{|c|}{7.42} & & & & \\
\hline $\mathrm{LSD}_{05}$ factor $\mathrm{B}$ & \multicolumn{3}{|r|}{8.18} & & & 0.87 \\
\hline $\mathrm{LSD}_{05} \mathrm{~A} \times \mathrm{B}$ & \multicolumn{3}{|r|}{26.76} & & & 1.28 \\
\hline
\end{tabular}

Note. Means in the same column followed by different letters represent significant differences at $P<0.05$ between treatments according to the Duncan's multiple range test; * - significant at the 0.05 level.

tested products on the minituber weight of the potato cultivars with different lengths of the growing season. Potato microclones of 'Goda' were found to have a positive tendency for minituber weight increase due to the application of PAA and GAA- $\mathrm{K}_{2} \mathrm{SO}_{4}$; however, the differences from the control were insignificant $(P>$ 0.05). Only the removal of stems at the stage BBCH 57 significantly increased $(+17.6 \%)$ the minituber weight of this cultivar. Decapitation was more efficient for 'VB Aista' with a longer growing period, especially, if performed during stage BBCH 57. The minituber weight significantly increased $(139 \%, P<0.05)$ compared both with the control treatment and with the effects of PAA and GAA- $\mathrm{K}_{2} \mathrm{SO}_{4}$. According to Evstratova and Nikolaeva (2016), the decapitation effect is not always positive, and depending on the climatic factors, it can also reduce the minituber yield.

Compared to the early cultivar 'Goda', the microclones 'of VB Aista' with a longer growing period were more sensitive to the use of biologically active products. All combinations of bioactive product application significantly increased the minituber weight. A higher yield increase of minitubers $(P<0.05)$ was obtained by applying a mixture of PAA and GAA$\mathrm{K}_{2} \mathrm{SO}_{4}$ twice during the growing season, that is, when the stimulatory effect of amino acids on the development of plants was combined with the regulatory effect on osmotic pressure in cells. Butt et al. (2016) carried out the studies on proline efficacy for reducing salt concentration stress, and also found that its effect on plant development depended on a genotype.

A correlation regression analysis revealed a strong positive correlation between minituber weight and nitrogen concentration in the leaves at the flowering stage, and a strong negative correlation between minituber weight and carbohydrate concentration (Figs 3 and 4). It should be noted that the productivity of 'VB Aista' with a longer growing period was more dependent on the concentrations of nitrogen and carbohydrates in the vegetative mass compared to the early cultivar 'Goda'.

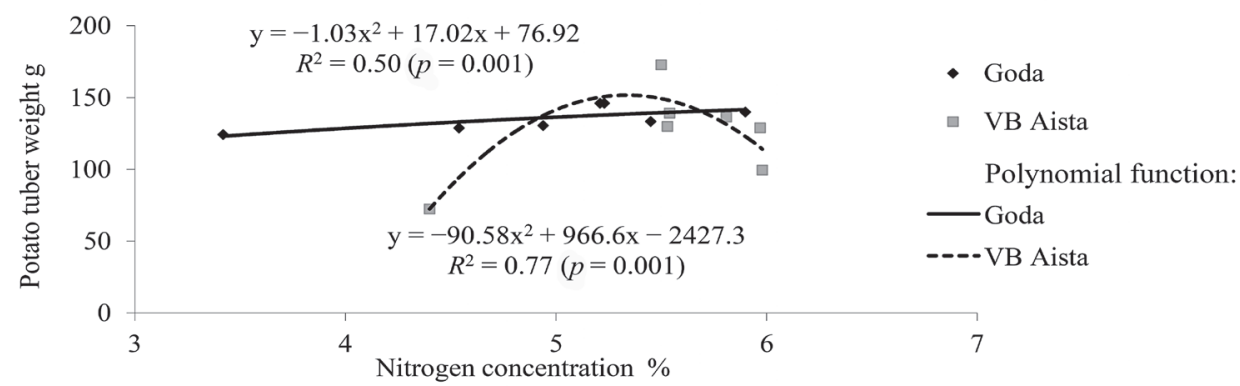

Figure 3. The relationship between minituber weight and nitrogen concentration in leaves at the flowering stage (BBCH 69)

Number of minitubers. While producing meristem potato seed material it is not only important to increase the weight of minitubers, but also to increase the number of minitubers and obtain tubers of a larger size, as they can be further propagated in the field, thereby reducing the costs of virus-free seed propagation. Struik (2007) summarises the results of various studies and indicates that 1 microplant usually forms $2-5$ minitubers; however, the differences between cultivars can be substantial - from $0.26-3.07$ to $7.00-8.31$. Potatoes of cultivars 'Goda' and 'VB Aista' produced an average of 8.22-8.24 minitubers per plant and their number did not depend on the genotype $(P>0.05)$. The treatment of microclones with biologically active substances and the removal of stem tops had a positive effect on minituber formation; however, a significantly higher number $(+17.2 \%, P<0.05)$ of minitubers was found in the treatment where microclones were applied with PAA twice during the growing period. 


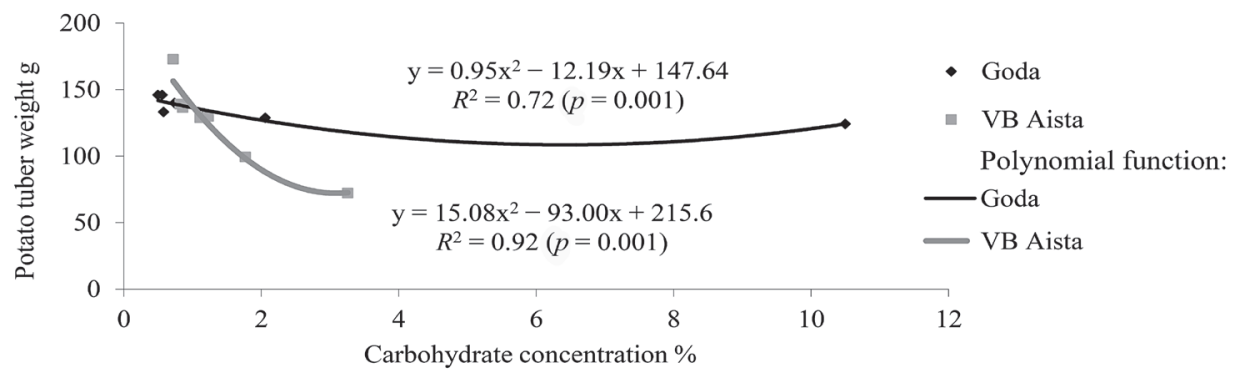

Figure 4. The relationship between minituber weight and carbohydrate concentration in leaves at the flowering stage (BBCH 69)

The results of minituber analysis data for each potato cultivar according to Duncan's test showed that the bioactive substances PAA and GAA-K $\mathrm{SO}_{4}$ had a tendency to increase their number in the early cultivar 'Goda', but the differences from the control were insignificant. Only stem decapitation significantly $(P<0.05)$ increased the formation of minitubers compared to the control treatment and bioactive substances. Potatoes of the cultivar 'VB Aista' with a longer growing period significantly increased the number of minitubers after treatment with GAA- $\mathrm{K}_{2} \mathrm{SO}_{4}$ or PAA twice during the growing season. However, the removal of stems at the stage $\mathrm{BBCH} 57$ resulted in an even higher increase in the minituber number. A substantial increase $(22.5 \%, P>0.05)$ in the minituber number was observed both compared with the control and with bioactive substances.

\section{Conclusions}

1. The bioactive products proline amino acid (PAA) Prolis and glutamic amino acid and potassium sulphate $\left(\mathrm{GAA}_{2} \mathrm{~K}_{2} \mathrm{SO}_{4}\right.$ ) Pompa did not have any significant effect on the productivity of the microclone potato early cultivar 'Goda'; however, the trend of minituber weight increase was obvious. The weight and number of minitubers were significantly $(P<0.05)$ increased by stem top decapitation carried out at the stage BBCH 57.

2. Microclone productivity of the potato late cultivar 'VB Aista' was effectively enhanced by the use of bioactive products PAA and GAA- $\mathrm{K}_{2} \mathrm{SO}_{4}$. A higher minituber weight was achieved by using PAA and GAA$\mathrm{K}_{2} \mathrm{SO}_{4}$ mixture once or twice per growing period $(P<$ $0.05)$. Significantly higher $(P<0.05)$ minituber weight per plant was obtained after stem decapitation at the stage $\mathrm{BBCH}$ 57. This measure significantly increased the number of minitubers compared to the effects of bioactive products.

3. The tuber weight of microclones strongly correlated with nitrogen concentration (positive correlation $R_{\mathrm{Goda}}-0.70, R_{\mathrm{VB} \text { Aista }}-0.87$ ) and carbohydrate concentration (negative correlation $R_{\text {Goda }}-0.85, R_{\mathrm{VB} \text { Aista }}-$ $0.96)$ in potato leaves at the flowering stage (BBCH 69).

\section{Acknowledgments}

The paper presents research findings obtained through the long-term research programme "Biopotential and quality of plants for multifunctional use", implemented by Lithuanian Research Centre for Agriculture and Forestry.

Received 01082018

Accepted 05022019

\section{References}

1. Ahmad Z., Anjum S., Waraich E. A., Ayub M. A., Ahmad T., Tarig R. M. S., Ahmad R., Iqbal M. A. 2018. Growth, physiology, and biochemical activities of plant responses with foliar potassium application under drought stress - a review. Journal of Plant Nutrition, 41 (13): 1734-1743. https://doi.org/10.1080/01904167.2018.1459688

2. Ali Q., Ashraf M., Shahbaz M., Humera H. 2008. Ameliorating effect of foliar applied proline on nutrient uptake in water stressed maize (Zea mays L.) plants. Pakistan Journal of Botany, 40 (1): 211-219.

3. Alwan A. H., Fathi S. M. A. 2013. Nutritional status of roselle plant (Hibiscus sabdariffa L.) under different levels of potassium and proline. Journal of International Scientific Publications: Agriculture and Food, 1 (1): 25-32. http:// www.scientific-publications.net

4. Bautista Condori F. A., Mita Quisbert V. F., Mamani Reynoso F. 2018. Effect of floral decapitation on the yield of three varieties of native potatoes (Saq'ampaya, Qhati Señorita and Imilla Negra) in the Bolivian Northern Highland. Revista de Investigación e Innovación Agropecuaria y de Recursos Naturales, 5 (1): 47-58 (in Spanish).

5. Ben Ahmed C., Ben Rouina B., Sensoy S., Boukhriss M., Ben Abdullah F. 2010. Exogenous proline effects on photosynthetic performance and antioxidant defense system of young olive tree. Journal of Agricultural and Food Chemistry, 58 (7): 4216-4222. https://doi.org/10.1021/jf9041479

6. Butt M., Ayyub C. M., Amjad M., Ahmad R. 2016. Proline application enhances growth of chilli by improving physiological and biochemical attributes under salt stress. Pakistan Journal of Agricultural Science, 53 (1): 43-49. https://doi.org/10.21162/PAKJAS/16.4623

7. Chen Z., Cuin T. A., Zhou M., Twomey A., Naidu B. P., Shabala S. 2007. Compatible solute accumulation and stress-mitigating effects in barley genotypes contrasting in their salt tolerance. Journal of Experimental Botany, 58 (15-16): 4245-4255. https://doi.org/10.1093/jxb/erm284

8. Desta B., Tsegaw T. 2008. Effect of removal of buds and younger leaves on growth, tuber yield and quality of potato (Solanum tuberosum L.) grown under hot tropical lowland. East African Journal of Sciences, 2 (2): 124-129. https://doi.org/10.4314/eajsci.v2i2.40371

9. Dimante I., Gaile Z. 2014. Potato minitubers technology - its development and diversity: a review. Proceedings of $20^{\text {th }}$ international scientific conference Research for Rural Development. Jelgava, Latvia, vol. 1, p. 69-76.

10. El-Sherbeny M. R., Teixeira da Silva J. A. 2013. Foliar treatment with proline and tyrosine affect the growth and yield of beetroot and some pigments in beetroot leaves. Journal of Horticultural Research, 21 (2): 95-99. https://doi.org/10.2478/johr-2013-0027

11. Evstratova L. P., Nikolaeva E. V. 2016. Decapitation of potatoes plants in the conditions of Karelia. Scientific notes of the Petrozavodsk State University, 4 (157): 38-41 (in Russian). 
12. Farooq M., Nawaz A., Chaudhry M. A. M., Indrasti R., Rehman A. 2017. Improving resistance against terminal drought in bread wheat by exogenous application of proline and gamma aminobutyric acid. Journal of Agronomy and Crop Science, 203 (6): 464-472.

https://doi.org/10.1111/jac. 12222

13. Farzana K. 2014. Improving drought tolerance in wheat by exogenous application of proline: MS thesis. Bangladesh Agricultural University, $66 \mathrm{p}$.

14. Haghighi Z., Karimi N., Modarresi M., Mollayi S. 2012. Enhancement of compatible solute and secondary metabolites production in Plantago ovata Forsk. by salinity stress. Journal of Medicinal Plants Research, 6 (18): 34953500. https://doi.org/10.5897/JMPR12.159

15. Hayat S., Hayat Q., Alyemeni M. N., Wani A. S., Pichtel J., Ahmad A. 2012. Role of proline under changing environments. Plant Signaling and Behavior, 7 (11): 1456-1466.

https://doi.org/10.4161/psb.21949

16. Kaya C., Tuna A. L., Ashraf M., Altunlu H. 2006. Improved salt tolerance of melon (Cucumis melo L.) by the addition of proline and potassium nitrate. Environmental and Experimental Botany, 60 (3): 397-403. https://doi.org/10.1016/j.envexpbot.2006.12.008

17. Lei P., Xu Z., Liang J., Luo X., Zhang Y., Feng X., Xu H. 2016. Poly $(\gamma$-glutamic acid) enhanced tolerance to salt stress by promoting proline accumulation in Brassica napus L. Plant Growth Regulation, 78 (2): 233-241. https://doi.org/10.1007/s10725-015-0088-0

18. Nunes E. N., Montenegro I. N. D., Fernandes Y. T. D., Nascimento D. A. M., Nascimento R., Alves C. A. B., Souto J. S. 2014. Biochemical responses of maize (Zea mays L.) cultivars subjected to nitrate and glutamine fertilizers. African Journal of Agricultural Research, 9 (50): 3663-3671.
19. Struik P. C. 2007. The canon of potato science: 25. Minitubers. Potato Research, 50 (3-4): 305-308. https://doi.org/10.1007/s11540-008-9051-z

20. Struik P. C., Wiersema S. G. 2012. Seed potato technology. Wageningen Academic Publishers, p. 185-193.

21. Takeuchi M., Arakawa C., Kuwahara Y., Gemma H. 2008. Effects of L-proline foliar application on the quality of 'Kosui' Japanese pear. ISHS Acta Horticulturae, 800 (72): 549-554. https://doi.org/10.17660/ActaHortic.2008.800.72

22. Teh C. Y., Shaharuddin N. A., Ho C. L., Mahmood M. 2016. Exogenous proline significantly affects the plant growth and nitrogen assimilation enzymes activities in rice (Oryza sativa) under salt stress. Acta Physiologiae Plantarum, 38: 151. https://doi.org/10.1007/s11738-016-2163-1

23. Tkachenko O., Evseeva N., Boikova N., Matora L. Burygin G., Lobachev Y., Shchyogolev S. 2015. Improved potato microclonal reproduction with the plant growth-promoting rhizobacteria Azospirillum. Agronomy for Sustainable Development, 35 (3): 1167-1174. https://doi.org/10.1007/s13593-015-0304-3

24. Valentovič P., Luxova M., Kolarovič L., Gašparikova O. 2006. Effect of osmotic stress on compatible soluted content, membrane stability and water relations in two maize cultivars. Plant, Soil and Environment, 52 (4): 186-191. https://doi.org/10.17221/3364-PSE

25. Zahoor R., Dong H., Abid M., Zhao W., Wang Y., Zhou Z. 2017. Potassium fertilizer improves drought stress alleviation potential in cotton by enhancing photosynthesis and carbohydrate metabolism. Environmental and Experimental Botany, 137: 73-83.

https://doi.org/10.1016/j.envexpbot.2017.02.002

\title{
Bulvių mikroklonų produktyvumo didinimas prolino bei glutamo rūgščių produktais ir stiebų dekapitacija
}

\author{
L. Tripolskaja, A. Ražukas \\ Lietuvos agrarinių ir miškų mokslų centro Vokès filialas
}

\begin{abstract}
Santrauka
Siekiant sumažinti augalų stresą plačiai naudojami įvairūs augimo reguliatoriai, kurie padeda palaikyti reikiamą osmosinị slègị ląstelèse ir apsaugo nuo didesnès druskų koncentracijos mitybinèje terpeje. Eksperimento tikslas - nustatyti aminorūgščiu pagrindu pagamintų bioaktyvių produktų Prolis (prolino rūgštis) bei Pompa (glutamo rūgštis ir kalio sulfatas, GAA- $\mathrm{K}_{2} \mathrm{SO}_{4}$ ) ir stiebų dekapitacijos įtaką skirtingos vegetacijos trukmès - ankstyvosios veislès 'Goda' ir labai vèlyvos veislès 'VB Aista' - valgomosios bulvès (Solanum tuberosum L.) mikrogumbu reprodukcijai. Aminorūgščiu produktai per vegetaciją buvo panaudoti vieną (po mikroklonų persodinimo i substratą) arba du (po mikroklonų persodinimo ị substratą ir po 30 dienų) kartus. Stiebų dekapitacija atlikta BBCH 51 ir 57 vystymosi tarpsniais. Nustatyta, kad produktų Prolis ir Pompa ịtaka mikroklonų produktyvumui priklause nuo bulvių genotipo. Vèlyvosios veislès 'VB Aista' bulvių gumbų masè esmingai $(P<0,05)$ padidẻjo po augalu apdorojimo produktu Pompa vieną arba du kartus per vegetaciją. Stiebų dekapitacija BBCH 57 tarpsniu esmingai didino abiejų veislių bulvių gumbų masę ir veislès 'VB Aista' bulvių gumbų skaičių. Nustatytas gumbų masès stiprus teigiamas priklausomumas nuo azoto koncentracijos bulvių lapuose žydejjimo tarpsniu.
\end{abstract}

Reikšminiai žodžiai: bioaktyvūs produktai, glutaminas, minigumbai, prolinas. 